\title{
Application of E-Wallet: A Preliminary Analysis from the Shariah Perspective
}

\author{
Adlin Zulkefli(1), Hanum Rusmadi(2), Akhtarzaite Hj Abd Aziz(3)
}

\begin{abstract}
The introduction of the digital wallet known as "E-Wallet" helps people in their transactions without the need for cash, which is known as the phenomenon of "go cashless." Implementation of the e-wallet is involved with some transactions and concepts used, which may trigger Shariah issues; this is the research problem. Therefore, there is a need to study this concept and its application by looking into the related Shariah requirements in order to clarify the hukm of using the ewallet for Muslim users. This paper aims to analyze the concepts used in the e-wallet from a Shariah perspective (takyif Fiqhī) and to highlight issues that are related to its application. This research uses the inductive approach in finding classical and contemporary references, as well as the analytical approach in relation to the Shariah concepts and issues. Finally, this research concludes with several findings: 1) the concept of wadī'ah can be adopted for the e-wallet as long as there is no usage from the platform provider; 2) it was found that the implementation of cashbacks does not involve riba payment; 3) lastly, there are some key challenges in implementing the e-wallet fully in Malaysia, especially in terms of the security risk.
\end{abstract}

Keywords: E-Wallet, Takyīf Fiqhī, Wadīah, BNM.

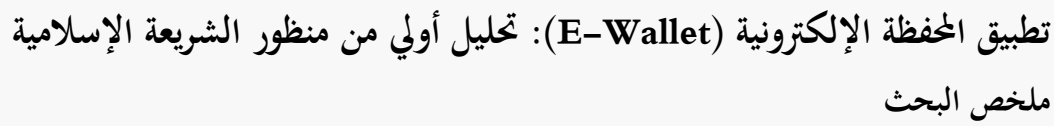

استعمال المحفظة الإلكترونية المعروف ب "E-wallet" (إي-والت) يعين الناس في معاملاقمم بدون حاجة إلى النقود المعروف بظاهرة "go cashless". ولعل مشكلة البحث تكمن في تطبيق المحفظة الإلكترونية الذي يتعلق ببعض المعاملات والمفهوم المطبق الذي يثير بعض المشاكل الشرعية. لذلك، هناك حاجة لدراسة مفهوم المحفظة الإلكترونية وتطبيقاتما من خلال النظر في المتطلبات الشرعية المتعلقة بهما لكي يمكن توضيح الحكم الشرعي لاستخدامها

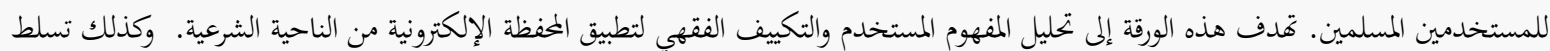
الضوء على القضايا المتعلقة بتطبيقها. يستخدم هذا البحث المنهج الاستقرائي للحصول على المراجع الفقهية قديما وحديثا وكذلك المنهج التحليلي فيما يتعلق بالمفاهيم وقضايا الشريعة الإسلامية. أخيرًا، توصل البحث إلى عدة نتائج آتية: 1) التكييف الفقهي للمحفظة الإلكترونية هذه هو الوديعة ما دام

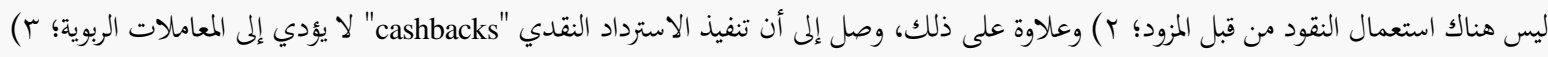
أخيرًا، هناك بعض التحديات في ماليزيا التي لا بد من مواجهتها في تطبيق المفظة الإلكترونية بكامله وهي تكمن في المخاطر الأمنية. كلمات مفتاحية: إي-والت، التكييف الفقهي، الوديعة، البنك المركزي الماليزي.

(1) Master Student, Dept. of Fiqh and Usul al-Fiqh, International Islamic University Malaysia. adlin.zkl95@gmail.com

(2) Master Student, Dept. of Fiqh and Usul al-Fiqh, International Islamic University Malaysia. hanumrusmadi92@gmail.com

${ }^{(3)}$ Assist. Prof., Dept. of Fiqh and Usul al-Fiqh, International Islamic University Malaysia. akhtarzaite@iium.edu.my

\section{Contents}

1. Introduction

2. Definition and Types of E-Wallet

2.1 E-Money

2.2 E-Wallet

3. E-wallet Modus Operandi and Shariah Adaptation

3.1 FAVE

3.2 Maybank MAE

3.3 Boost

4. Issues on E-Wallet

4.1 Challenges

4.2 Unstandardized

4.3 Security Risk
5. Conclusion

104

References

104

\section{Introduction}

It is an accepted fact that smartphones have replaced quite a number of applications used in laptops, computers and cameras. The use of smartphones has become dominant because of the convenience in accessing the internet. By 2020, it is estimated that there will be 2.6 billion connected smartphones in the world (Thad Peterson, Ron van Wezel, 2016).

A few years back, a new mobile wallet system was created by the domain of ICT (Information and Communication Technology) using mobile 
communication. This innovation and introduction of the mobile phone wallet is a big new opportunity in the area of business in terms of enhancing performance and will in turn continuously enable growth and sustainability. The advancement in this feature of the mobile phone has enabled applications which may support efficient business transactions as they make it easy for customers to transfer their payment via phone. As for now, the e-wallet is already an option and is starting to replace the traditional cash payment system slowly. Recently, people have widely started to accept this kind of digital payment due to its simplicity and secure features (Thad Peterson, Ron van Wezel, 2016).

Among the top countries which dominate the usage of the e-wallet is China. The use of e-wallets in China is quite extensive. As recorded in 2016, the mobile transaction was USD 9 trillion in China compared to about USD 112 billion in the US. This is due to the fact that China has over a billion in population with the highest number of mobile phone users in the world. Among the apps that contributed to this vibrancy are services such as WeChat Pay (Tencent) and Alipay (Alibaba). These two applications have contributed hugely in providing financial products and services (Kapital, 2018).

As the use of the e-wallet is getting wider in Malaysia, it has become pertinent to analyze the concept and contract of use according to the rule of jurisprudence. Malaysia is one of the most significant pioneers in Islamic Finance and is really spurring the greater adoption of mobile payments by introducing the Interoperable Credit Transfer Framework (ICTF) that establishes a shared payment infrastructure that connects any bank and non-bank accounts while managing the resultant risks. Malaysia has also introduced the Real-time Retail Payments Platform (RPP) that enables seamless and secure payments via the use of simple identifiers, such as mobile phone, Identity Card (IC), and business registration numbers, and the use of a common Quick Response (QR) code (Lee Zhi Wei, Daniel Khaw Peng Tsu, 2018).

The reformation of banks has opened significant opportunities for Malaysia in its efforts to migrate to epayment. As we notice, mobile payments have significant potential in reducing the usage of cash. There is a survey that found that the number of e-wallet users in Malaysia increased to 52.9 per cent of respondents in October 2017 compared to 24.3 per cent in February 2018. The e-commerce marketplace Carouse said the survey also recorded a three-fold increase in respondents from 202 in February 2018 to 731 in October 2018, which showed a dramatic increase in interest in the use of e-wallets in the country. Data from the survey also showed that the five major ewallets used by Carousell users were GrabPay, Touch n'Go e-Wallet, Boost, Maybank QRPay and WeChat Pay (BERNAMA, 2018).

From the above background view, this paper aims to analyze the concepts used in some of the ewallets' transactions from the Shariah perspective. Specifically, it focuses on suggesting the fiqh adaptation (takyīiff fiqhī) of the e-wallet. It will also focus on some of the potential issues regarding this topic.

\section{Definition and Types of E-Wallet}

In order to make things clear for the articulation of this article, it is crucial to define both e- money and the ewallet.

\subsection{E-Money}

Just like coins and notes, e-money is also another form of money/currency called electronic money. The fact that they exist electronically and not physically is what differentiates them from our traditional money.

Electronic money refers to money that exists in banking computer systems that may be used to facilitate electronic transactions. Although its value is backed by fiat currency and may, therefore, be exchanged into a physical, tangible form, electronic money is primarily used to transact electronically, due to the sheer convenience of this methodology. (Bloomenthal, 2019).

According to Bank Negara Malaysia (BNM), emoney can be defined as:

"a payment instrument that contains monetary value that is paid in advance by the user to the e-money issuer. The user of e-money can make payments for purchases of goods and services to merchants who accept the e-money as payment”. (BNM) 
This definition by BNM is very general where it merges both e-wallet and e-money in one definition.

\subsection{E-Wallet}

On the other hand, a digital wallet which is also known as the "e-wallet" refers to an electronic device or online service that allows an individual to make electronic transactions. This includes purchasing items on-line with a computer or using a smartphone to purchase something at a store. An individual's bank account can also be linked to the digital wallet (Digital wallet, 2019).

An e-wallet is a digital tool (software or application) for consumers to store their payment methods. It stores credentials such as debit and credit cards, and alternative payment methods. Some ewallets can also store loyalty programs. An e-wallet allows an individual to make electronic transactions with an improved checkout and payment experience compared to keying in all payment credentials every time a purchase is to be made. This wallet can function both online and in physical stores (Paypers) where users and merchants would normally scan either bar codes or QR codes for payment.

An e-wallet is just like a bank account where it basically stores e-money. E-money is money that has value and purchasing power and is used in transactions.

From these definitions, it can be concluded that the e-wallet is just like a physical wallet, only that it exists electronically, and the same goes for e-money. The difference between physical wallets and physical money is similar to the difference between electronic wallets and monies.

In Malaysia, specifically there are two types of e-money schemes, namely the large scheme and the small scheme. They are named based on the limit of the amount of money you can put in each wallet. The large scheme is where the limit is more than RM200 and the small scheme holds not more than RM200. In Malaysia, there are some e-wallets which can be linked directly to Visa/MasterCard (BNM).

BNM has provided a set of guidelines regarding e-money to ensure the safety of the system and in order to sustain the stability of the country's financial system, as this relates to the supply and demand of money.

These are some of the guidelines issued:

- Principle 1: Establish adequate governance and operational arrangements.

- Principle 2: Ensure that the proper risk management is in place.

- Principle 3: Ensure that the risks of using e-money, and the rights and responsibilities of all stakeholders are clearly defined and disclosed.

- Principle 4: Ensure the prudent management of funds.

- Principle 5: Ensure timely refund of stored value in the e-money.

- Principle 6: Implement adequate measures to prevent the use of e-money for money laundering, and ensure compliance with other requirements (BNM).

With these principles, users are protected by the law and only those who have met these requirements are eligible for licensing under BNM.

\section{E-Wallet Modus Operandi and Shariah Adaptation}

As there are different types of e-wallets with different business models, it is not fair to classify them all under one contract or one Shariah principle as they are in core, different. This section will analyze a few types of ewallets in Malaysia according to their business models/modus operandi and try to adopt suitable Shariah contracts for them (takyīf fiqhī) accordingly.

\subsection{FAVE}

Fave was originally a telco app (Axiata) for customers to top-up their lines and a lifestyle loyalty app which later developed into an e-wallet. It acts as a payment gateway for online transactions. It does not retain any money and only facilitates the transfer of money from the users' bank account to the merchants'. The Shariah contract used is ujrah or service, in which Fave mediates payments from customers to sellers. Fave will then collect its fee from merchants. It offers various rewards, such as cashbacks and discount vouchers to users as a marketing strategy. This poses no Shariah issues as ujrah is permissible in Islam (GoBear Comparison Made Easy, 2018). 


\subsection{MAYBANK MAE}

Maybank Anytime Everyone (MAE) is an e-wallet that is directly provided by Maybank. This MAE is a part of the maybank $2 \mathrm{u}$ mobile application service. Users will need to top up their wallet by transferring money into their e-wallets which can be done via Cash Deposit Machines (CDM), online transfers, Financial Process Exchange (FPX), or by using their debit cards.

This wallet acts like a trust account as it stores money. Hence the presumed Shariah contract would be either qard or wadiah. Since they limit the amount to RM4999 only to lower the risk of losses, it is presumed to be under the wadiah contract as they do not guarantee that the users' money is insured by PIDM (Product Disclosure Sheet-MAE, 2019). But since the Shariah contract used in trust accounts is qard, it can also be presumed that the contract for this e-wallet follows that of the trust accounts. Nevertheless, the fact that they are not protected under PIDM - as the money is not guaranteed - gives a clear distinction between the two. Hence, the researcher is more inclined to adopt wadiah in this case, noting that the money in these wallets are not used by Maybank, as such usage of this money would automatically violate the wadiah principle in general.

The controversial issue raised by the public is when the game built in this app offers rewards to users in monetary form. If the contract pegged is qard, will then the monetary rewards be considered as riba hence making it non-Shariah compliant (NSC)? But if the contract pegged is wadiah, any type of reward would not pose any Shariah issue and can be considered as hibah. This issue shall be discussed further in the next case study.

\subsection{BOOST}

It is a full-fledged e-wallet where it does not link to a bank account nor is it provided by a banking entity. It acts exactly like a physical wallet only and it exists electronically in the phone. Users need to top up their e-wallets by transferring money into these wallets before they are able to use them for any transactions. The money deposited in these wallets is put in a trust account where the presumed Shariah contract is qard or wadiah as aforementioned.
In the case of Boost, these are some clauses related to its liability (Boost's Liability and Liability for service, 2019).

10.1 Boost shall not be liable for any liability, loss, damages, cost and/or expenses (whether direct or indirect), or for loss of revenue, loss of business, loss of profits or any consequential or indirect loss whatsoever as a result of your use and/or misuse of the Service.

10.7 Notwithstanding anything to the contrary contained herein, the maximum liability of Boost shall not exceed an amount equivalent to the aggregate sum of the Available Balance of your Account at the date on which your claim arises.

11.1 Boost shall not be liable for any special, indirect or consequential damages or any damages whatsoever, whether in an action of contract, negligence or other tortuous action, arising out of, or in connection with the performance of, or use of Services available on the App and in particular, but without limitation to the foregoing, Boost specifically excludes all liability whatsoever in respect of any loss arising as a result of: (a) use which you make of the App and the Services, or reliance on Services, or any loss of any Services resulting from delays, non-deliveries, missed deliveries, or service interruptions; and

(b) defects that may exist for any costs, loss of profits, or consequential losses arising from your use of, or inability to use or access, or a failure, suspension or withdrawal of all or part of the App and the Services at any time.

Based on these clauses, Boost will only compensate if proven to be negligent. This means that the concept is just like the classical wadiah where the keeper is not liable for compensation unless the object is broken or damaged because of his negligence. In the classical wadiah concept, the object given to the keeper shall not be used by the keeper. If the keeper uses the object, then the contract will automatically change to qard and he is liable for compensation.

The issue here is the question of whether or not Boost - and other e-wallet providers - use the money deposited in the wallet? According to the guidelines issued by BNM: 
13.1(ii) An issuer of e-money shall not use the money collected to extend loans to any other persons.

10.2 An issuer of a large e-money scheme should deposit the funds collected in exchange of the e-money issued in a trust account with a licensed institution in a timely manner, which shall be governed as follows: (a) The trust account shall be established in accordance with the Trustee Act 1949; (b) The funds can only be used for the following:(i) refund to users; and (ii) payment to merchants.

10.2(c) The funds may only be invested in high quality liquid ringgit assets which are limited to deposits placed with licensed institutions; debt securities issued or guaranteed by the Federal Government and Bank Negara Malaysia; Cagamas debt securities, and other instruments as may be specified by the Bank;

10.3 For issuers of a small e-money scheme, the funds collected in exchange of the e-money issued, should be placed in a deposit account with a licensed institution, separated from its other accounts,

10.3(b) The funds shall not be invested in any form of assets other than as bank deposits (BNM).

Based on these clauses, it is hard to classify whether these deposited monies are regarded as qard or wadiah as the characteristics are a mixture of the two.

The situation today in Malaysia is that the issuer does not use and cannot use the users' deposited money and is required to 'safekeep' them in a trust account. This agrees with the classical wadiah concept as aforementioned. However, BNM also allows the fund to be invested in high quality liquid ringgit assets. The fact that the money can be used for investment but is limited to those of high liquidity and almost zero-risk raises the question of whether this nullifies it as wadiah as the money is almost guaranteed and is in fact, being used by the provider. Hence, the researcher suggests that a deeper and further research be conducted on the concept of contemporary wadiah for money to answer these questions:

Are cashbacks, rewards and discount vouchers to users considered to be riba?

As some e-wallets offer various kinds of rewards to users, some of which are in monetary form, this might trigger some serious Shariah issues as rewarding or promising money on money is considered riba which is prohibited in Islam. However, al-Umrani (n.d.) in his writing mentioned some important points to look at, as follows:

"If the borrower decides to give out any kind of benefit (manfaah) to the lender without having any preagreement to them beforehand, and before he settles the loan, for example: giving hadiyyah, benefit of riding the camels (transportation), or helping out the lender in his work, there are two views on this and the preferable view (ar-rajih) is of prohibiting these manafi if they are because of the loan, i.e to get extension from the date of payment, to get loan for the second time ...". (al-Umrani, n.d.).

This confirms that any benefit which includes monetary and non-monetary, given to the lender because of the loan he gave out is riba and thus prohibited. In this case, there are a few important questions that came across the researcher's mind that need clarification. Firstly, whether these rewards are from the issuer (المقترض) itself or from a third party which they collaborate with, such as eatery companies like Tealive, aviation companies like Air Asia, and beauty and cosmetics companies where users are usually offered discount vouchers and cashbacks when they make transactions using e-wallets. The second question is regarding the business models of the ewallet companies, as their main business is to provide the platform and payment services and does not extend to giving loans to people. Hence, these rewards can be presumed to be merely a marketing strategy to attract more users to use the platform and are not related to the money deposited in the wallets.

Therefore, the researcher is more inclined to refer to the concept of hibah for cashbacks and rewards as per the reasons mentioned above, and to consider them Shariah compliant.

BNM has issued some prohibition guidelines for issuers and these guidelines conform to the Shariah. They are as follows:

An issuer of e-money shall not:

- issue the e-money at a discount, i.e. issue e-money that has a monetary value greater than the sum received;

- use the money collected to extend loans to any other persons; 
- extend credit to the user, or pay interest or profit on the e-money balances, or anything else that would add to the monetary value of the e-money; and

- associate, link or use the e-money scheme or platform to conduct illegal activities (BNM).

These guidelines indirectly avert riba as it is crucial for BNM to maintain financial stability in the country and also to promote a sound system which can be trusted by the public.

The service provided by these companies can be considered under the ujrah contract, where the service fee is paid by the merchant. Christopher Tiffin, the CEO of Boost, revealed that for the first year, Boost would not be charging merchants for the usage of its mobile wallet system, arguing that this is one way to further drive adoption (Yapp, 2018).

There are a few ways these e-wallet companies make money which include charging a monthly fee to merchants for providing the platform, charging for advertisements, through collaborations with other companies, and by charging fees to banks for customers using credit/debit cards, just to name a few (Kumar, 2017). All these contracts are considered to be providing services and thus are said to be classified as following the ujrah concept which also poses no Shariah issues.

\section{Issues on E-Wallet}

\subsection{Challenges}

E-wallets are widely used in China and South Korea but are not widespread in South Asia, including Malaysia. Some of the banks do not see phone payments as a top priority at this moment which makes it a big challenge for e-wallet companies to find the right partners to collaborate with.

However, Touch N' Go Digital company in Malaysia has started to study the China model to see how it can be implemented in Malaysia. As we know, the TNG wallet is used for transportation payments and this company will continuously produce more research to come out with more use cases and services such as paying for parking and more (Nair, 2018).

Malaysians are familiar with other cashless systems called card payments. To compare with China, this country has no problem in going straight from cash to e-payment as they don't rely much on card payment. In China, they had to combine the e-wallet innovation with China's e-commerce boom and WeChat. So, this foundation has already supported the growth of the ewallet Alipay and WeChat Pay, which now dominate the market. However, this is quite hard to adopt in local Malaysian e-wallets, as they have to contend with what already exists, which is swiping a piece of plastic (cards) (Pikri, 2018).

\subsection{Unstandardized}

For the market in Malaysia, the e-wallet seems not so unique as Malaysia already has good and stable systems for online payments such as the credit card, debit card and so on. Not only that, Malaysia also has so many ways of payment when it comes to digital payment, so the adoption of the e-wallet seems confusing to the public as another way. Moreover, the emergence of different e-wallets may have made it worse as there is no one "general e-wallet" which can be accepted by most merchants and this means a lot of types of e-wallet need to be installed (Pikri, 2018).

As such, in December 2016, only 36\% of retailers accepted Apple Pay and 34\% retailers accepted PayPal while only $25 \%$ accepted MaterPass as the form of payment, which shows that this e-wallet is not fully available worldwide (Gaille, 2018).

In the case of many of the e-wallets in Malaysia, during their introduction to users, one more step was required in the payment process instead of just swiping a card. Users have to transfer money to their e-wallet and only after that they can make payments. This phenomenon is quite inconvenient for consumers. As a result, these e-wallet companies constantly offer discounts, incentives, and zero merchant fees. Hence, they face high marketing costs to ensure that Malaysians will adopt this payment method (Pikri, 2018).

\subsection{Security Risk}

Regarding the security risk, there is still disagreement on how secure the e-wallet to be used by customers is. There are successful hackers who can penetrate the system and gain access to the money in the wallet and the stored information by obtaining the user's financial 
details. It is much worse when the non-tech savvy is robbed compared to a regular owner of the e-wallet. Plus, non-tech savvy users have to employ strong and often-changed passwords to ward off potential hackers (Sachdev, n.d.).

According to the Cyber Security Malaysia (CSM) chief executive officer Datuk Dr Amirudin Abdul Wahab, there are two incidents involving block chain e-wallet that have been reported to CSM. These two incidents involved fraudulent transactions and an e-wallet account being compromised. The report said the victim of one of the cases only realized that the balance of the account had been reduced and was being transferred to a suspicious e-wallet address without the user's authorization (Meikeng, 2019).

Other cases related to scams and risks faced by users include hacking which allows criminals to access devices and sensitive data, phishing attacks and luring the users to reveal password and other private data (Meikeng, 2019).

It became worse because some of the companies that provide this method of payment will not guarantee the amount of money stored in the account if such a case happens. This is as stated in the contract of Maybank Anytime Everywhere (MAE) that the money in the account is not insured by Perbadanan Insurans Deposit Malaysia (PIDM) (Product Disclosure SheetMAE).

Another obvious risk is if we lose our phone, we will also lose the e-wallet, if it's not hosted on the internet service. This may also happen if our device's battery runs out, and we lose the ability to access the ewallet in that particular time (Meikeng, 2019).

\section{Conclusion}

As the e-wallet is a step towards modernizing the society, a change in the way of handling things, it is a good thing to try every existing e-wallet in the country just to find the best. Nonetheless, it is also very crucial to understand how each and every one of them works and find out if there are any possible Shariah issues for which measures should be taken.

This paper can be concluded with several findings; to find out the exact takyiif fiqhi of the funds in the e-wallets, further deliberation through the
Shariah viewpoint would be needed. However, the researcher is inclined towards adopting the concept of wadiah as long as the money is not used by the platform providers. Secondly, cashbacks are considered to be Shariah compliant based on the reasons aforementioned. Thirdly, although there are challenges for these e-wallet companies, it is true that the e-wallet is indeed an important milestone in advancing our payment system methods as they have brought about improved convenience which will in turn enhance efficiency and increase the volume of trade.

\section{References}

al-Umrani, A. b. (n.d.). Al-Manfaat fi al-Qard Dirasah Ta'siliyyah Tatbiqiyyah. Retrieved from http://iefpedia.com/arab/wp-

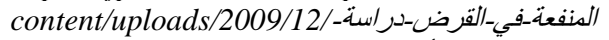
تأصيلية-تطبيقية-عبد-الله-بن-محمد_/العمراني

BERNAMA. (2018, December 20). Pengguna e-dompet Malaysia kian meningkat - Carousell. Retrieved from BH Online: https://www.bharian.com.my/bisnes/lainlain/2018/12/511374/pengguna-e-dompet-malaysiakian-meningkat-carousell

Bloomenthal, A. (2019, May 15). Electronic Money. Retrieved from Investopedia: https://www.investopedia.com/terms/e/electronicmoney.asp

BNM. (n.d.). Guideline on Electronic Money. Retrieved from $B N M$ :

http://www.bnm.gov.my/microsite/ps/gl_016_3.pdf

Boost's Liability and Liability for service. (2019, May 9). Retrieved from Boost: https://www.myboost.com.my/terms-conditions/

Digital wallet. (2019, May 20). Retrieved from Wikipedia: https://en.wikipedia.org/wiki/Digital_wallet

Gaille, B. (2018, August 27). 13 Electronic Wallets Advantages and Disadvantages. Retrieved from Brandon Graille Small Business \& Marketing Advice: https://brandongaille.com/13-electronicwallets-advantages-and-disadvantages/

GoBear Comparison Made Easy. (2018, November 7). Retrieved from https://www.gobear.com/my/blog/8popular-e-wallets-trending-in-malaysia-right-now

Kapital. (2018, April 6). Bisnes Perlumbaan E-wallet di Malaysia. Retrieved from Kapital: https://kapital.my/2018/04/bisnes-perlumbaan-ewallet-di-malaysial

Kumar, R. (2017, March 9). How do companies of mobile wallet earn money? Retrieved from Quora: https://www.quora.com/How-do-companies-ofmobile-wallet-earn-money

Lee Zhi Wei, Daniel Khaw Peng Tsu. (2018). Transforming Mobile Phones into E-Wallets in Malaysia. Retrieved 
from BNM QUARTERLY BULLETIN:

http://www.bnm.gov.my/files/publication/qb/2018/Q 2/p7.pdf

Maybank. (n.d.). MAE (Maybank E-Wallet). Retrieved from www.maybank2u.com.my: https://www.maybank2u.com.my/iwovresources/pdf/personal/digital_banking/MAE_FAQ. $p d f$

Meikeng, Y. (2019, February 3). Cashing in on e-wallets. Retrieved https://www.thestar.com.my/news/nation/2019/02/03 /cashing-in-on-ewallets-its-a-growing-trend-morepeople-are-using-ewallets-in-their-phones-thesedays/

Money MAE-Hem. (n.d.). Retrieved from maybank2u. https://www.maybank2u.com.my/iwovresources/pdf/personal/digital_banking/MoneyMAE Hem_TnC.pdf

Nair, V. (2018, October 19). The problem with e-wallets? There are just too many of them, say fintech experts. Retrieved from Techinasia: https://www.techinasia.com/problem-with-ewalletschina-conference-2018

Paypers, T. (n.d.). Ecosystem explained: payment methods and e-wallets. Retrieved from www.thepaypers.com: https://www.thepaypers.com/documents/ecosystemexplained-payment-methods-and-e-wallets.pdf

Pikri, E. (2018, July 20). How Many E-Wallets is Too Many Wallets In Malaysia? Retrieved from Fintech Malaysia: https://fintechnews.my/17900/paymentsremittance-malaysia/e-wallets-digital-paymentmalaysia-saturated/

Product Disclosure Sheet. (2019, March). Retrieved from maybank2u: https://www.maybank2u.com.my/iwovresources/pdf/personal/digital_banking/MAE_PDS.p $d f$

PRODUCT DISCLOSURE SHEET-MAE. (n.d.). Retrieved from MAE-Maybank2u: https://www.maybank2u.com.my/iwovresources/pdf/personal/.../MAE_FAQ.pdf

Sachdev, N. (n.d.). The evolution of ewallets: history, benefits and withdrawals. Retrieved from The sociable: https://sociable.co/mobile/evolution-ewalletshistory-benefits-withdrawals/

Thad Peterson, Ron van Wezel. (2016). The Evolution of Digital and Mobile Wallets. Delhi Headquarters: MAHINDRA COMVIVA.

Thad Peterson, Ron van Wezel. (2016). The Evolution of Digital and Mobile Wallets. Delhi Hearquarters: Mahindra Comviva.

Yapp, E. (2018, January 30). A year on, Axiata Digital tags on mobile wallet to Boost app. Retrieved from DNA. https://www.digitalnewsasia.com/business/yearaxiata-digital-tags-mobile-wallet-boost-app 